\title{
Impact of introduced herbivores on understory vegetation along a regional moisture gradient in Patagonian beech forests
}

\author{
María-Victoria Piazza ${ }^{a, *}$, Lucas A. Garibaldi ${ }^{b}$, Thomas Kitzberger ${ }^{c}$, Enrique J. Chaneton ${ }^{\text {a }}$ \\ a IFEVA-CONICET and Facultad de Agronomía, Universidad de Buenos Aires, Av. San Martín 4453, 1417 Buenos Aires, Argentina \\ ${ }^{\mathrm{b}}$ Grupo de Investigación en Agroecología (AGRECO), Sede Andina, Universidad Nacional de Río Negro and CONICET, Mitre 630, 8400 San Carlos de Bariloche, Argentina \\ ${ }^{\mathrm{C}}$ Laboratorio Ecotono, INIBIOMA-CONICET, Universidad Nacional del Comahue, Quintral 1250, 8400 Bariloche, Argentina
}

\section{A R T I C L E I N F O}

\section{Article history:}

Received 13 September 2015

Received in revised form 26 January 2016

Accepted 28 January 2016

\section{Keywords:}

Disturbance

Domestic ungulates

Herbivory

Functional types

Species diversity

\begin{abstract}
A B S T R A C T
Introduced ungulates can alter understory structure and composition posing a serious threat to forest biodiversity. Yet how large-herbivore impacts in forested regions vary along major environmental gradients remains little explored. If ungulate effects shift with habitat conditions, then management could be tailored to protect most vulnerable forests. We tested the hypothesis that the extent of livestock impact on understory vegetation increases with habitat moisture across Nothofagus dombeyi forests in Nahuel Huapi National Park, NW Patagonia, Argentina. Understory composition and species diversity were compared for paired sites $(N=5)$, which were historically used by cattle or remained free of livestock for more than $50 \mathrm{yr}$, and were located along a regional precipitation gradient (1500-2800 mm/yr). Long-term cattle presence reduced the cover of sub-canopy trees, shrubs and bamboo by $57-83 \%$, and increased the relative cover of ground-layer herbs, regardless of habitat moisture. Livestock effects on species composition increased towards the wettest forests, which contained more species exclusive to either browsed or unbrowsed sites. Livestock presence increased species richness ( $\alpha$ diversity) and within-site heterogeneity ( $\beta$ diversity) in some locations, but mostly reduced species evenness (30\%) throughout the moisture gradient. Species turnover at the gradient scale was lower across browsed sites than for livestock-free sites. Our results indicate that the historical presence of domestic cattle induced region-wide changes in understory communities, highlighting the vulnerable nature of the local flora to ungulate disturbance. The greater impact of livestock browsing on the species composition of wetter forests was consistent with the role of plant growth-defence trade-offs along resource gradients. We suggest that the erosion of understory vegetation attributed to domestic herbivores in Patagonian beech forests can be mitigated by adjusting current animal stocks, while moister forests should be given the highest conservation priority.
\end{abstract}

(c) 2016 Elsevier B.V. All rights reserved.

\section{Introduction}

The ecological impacts of exotic herbivores are a major conservation concern in forests worldwide. The introduction of ungulate herbivores may drastically alter understory structure and composition, affecting biodiversity from local to regional scales (Vázquez, 2002; Spear and Chown, 2009; Martin et al., 2010; Nuttle et al., 2011; Hegland et al., 2013), with consequences on multiple ecosystem functions (Pastor and Cohen, 1997; Wardle and Bardgett, 2004). Large herbivores interact with environmental conditions in creating the spatial patterning of vegetation observed at various scales (Senft et al., 1987; Adler et al., 2001; Frank, 2006). Yet, how

\footnotetext{
* Corresponding author.

E-mail address: victoriapiazza@gmail.com (M.-V. Piazza).
}

grazing/browsing impacts in forest communities vary across relevant ecological gradients remains little explored (Randall and Walters, 2011). If ungulate effects depend on environmental context as determined by habitat moisture or productivity, then management options could be tailored to prevent biodiversity loss from the most vulnerable forest sites.

Herbivore effects are expected to change with environmental conditions according to dominant plant species' traits and susceptibility to herbivory (Coley et al., 1985; Pastor and Cohen, 1997; Díaz et al., 2006). Several models predict an increase in the magnitude of grazing effects on plant composition along productivity or moisture gradients (Milchunas et al., 1988; Leibold et al., 1997; Chase et al., 2000). Weaker effects in less productive or drier systems may be explained by dominant species having traits that provide tolerance to low resource supply as well as resistance to 
herbivory (Coley et al., 1985). Conversely, herbivore-driven compositional changes in productive or moister habitats would reflect the prevalence of plant traits for aboveground competition, which render dominant species more susceptible to herbivory (Milchunas et al., 1988; Díaz et al., 2006). Thus, a dominance shift towards well-defended, less palatable species may be apparent under intense herbivory in productive sites (Leibold et al., 1997; Olff and Ritchie, 1998). In addition, ungulate herbivory may either increase or decrease plant diversity, depending on the balance between local colonization and extinction processes, and herbivore selectivity for competitive dominant vs. subordinate species (Milchunas et al., 1988; Olff and Ritchie, 1998). Herbivore effects on species richness and evenness are predicted to shift from negative to positive with increasing habitat productivity (Proulx and Mazumder, 1998; Hillebrand et al., 2007).

While hypotheses for context-dependent herbivore effects have gained support in grass-dominated systems (e.g. Milchunas and Lauenroth, 1993; Anderson et al., 2007; Lezama et al., 2014), they have barely been tested in forested landscapes (Randall and Walters, 2011). Studies in temperate and boreal forests often focus on ungulate density as a major driver of understory community structure (Wardle and Bardgett, 2004; Royo et al., 2010; Didion et al., 2011; Wright et al., 2012; Hegland et al., 2013). Few have addressed the interactive effects of herbivory and environmental gradients in shaping regional patterns of understory composition and diversity (Randall and Walters, 2011; Suzuki et al., 2013). In aspen forests of Michigan (USA), deer herbivory decreased forb biomass and plant richness mostly in high-productivity sites, but increased fern and sedge biomass in low-productivity ones (Randall and Walters, 2011). In contrast, in warm-temperate forests of Japan, deer herbivory was the main determinant of ground-layer species composition, irrespective of canopy openness and habitat moisture (Suzuki et al., 2013). In the latter study, plant richness peaked at intermediate herbivore densities (Suzuki et al., 2013), whereas in cool-temperate forests of Patagonia, the effect of exotic ungulates on species richness may vary with canopy cover (Vázquez, 2002). These examples suggest that general patterns for herbivore impacts in forested systems may be more elusive than expected from current grazing models.

Mechanisms affecting herbivore effects along productivity or moisture gradients in forest ecosystems may differ from those reported in grasslands due to differing dominant plant life forms. In grassland communities, large herbivores often suppress dominant grasses, making resources available to less competitive species (Milchunas and Lauenroth, 1993; Olff and Ritchie, 1998). In contrast, in closed-canopy forests, ungulates consume subordinate understory species (shrubs, trees) and ground-layer herbs, while canopy trees remain largely inaccessible. Further, understory species are generally constrained by their tolerance to shading (Grime, 2001; Coomes et al., 2009), and may be ill-equipped to regrowth after browsing, although they may still possess effective structural defenses (Bryant et al., 1983; Hanley et al., 2007). Browsing could thus exert similar impacts in forest communities along broad habitat gradients (Suzuki et al., 2013), unless higher light availability in less productive or drier sites favors fast-growing species with greater susceptibility to herbivory (Coley et al., 1985; Coomes et al., 2009). Ungulate browsers may also release low-growing herbs from shrub (Hegland et al., 2013) or bamboo competition (Darabant et al., 2007), and this indirect effect could be stronger in wetter forests with greater light limitation (Vázquez, 2002; Randall and Walters, 2011). At the regional scale, whether ungulate herbivores exacerbate or reduce vegetation patchiness will depend on the interplay between animal densities, the steepness of underlying environmental gradients, and the size and composition of plant species pools (Adler et al., 2001; Frank, 2006; Suzuki et al., 2013).
By changing the structure and composition of understory communities, large ungulates may also alter the amount and diversity of litter material transferred to the forest floor (Pastor and Cohen, 1997; Wardle and Bardgett, 2004). Herbivore-induced shifts in leaf-litter biomass and composition may affect belowground communities and ecosystem attributes such as soil carbon and nutrient cycling (Tanentzap and Coomes, 2011; Lessard et al., 2012; Hatton et al., 2014). Although interactions between above- and belowground processes have attracted much recent attention (Wardle and Bardgett, 2004), there is still little evidence to ascertain whether ungulate impacts at the level of the forest litter layer vary predictably along environmental gradients (Persson et al., 2005).

In this study, we examine the long-term impact of introduced livestock on understory vegetation of southern beech Nothofagus forests distributed along a region-wide moisture gradient in northern Patagonia, Argentina. Exotic ungulates were introduced into the study region during the late 1800s, and have been found to alter the structure and composition of understory communities (Veblen et al., 1989, 1992; Vázquez, 2002; Raffaele et al., 2007, 2011; Relva et al., 2008, 2010). Yet, previous studies inferred ungulate impacts from browsing metrics and short-term exclosures in single habitats, and were thus limited by the lack of historical reference sites in various environmental contexts (cf. Veblen et al., 1992). Here we examine the hypothesis that the impact of domestic herbivores on understory communities increases with habitat moisture. Nothofagus dombeyi stands that were either historically ( $>50$ years) used by or remained free of livestock were compared along a $1300 \mathrm{~mm} / \mathrm{yr}$ precipitation gradient. It was assumed that this moisture gradient encompassed a range of ecological conditions and species composition that were relevant for vegetation responses to livestock disturbance (Veblen et al., 1992; Speziale et al., 2010). We expected differences in vegetation attributes between (paired) browsed and unbrowsed sites to increase from drier to wetter forests, while differences across forest habitats would be mostly apparent for livestock-free sites. Specifically, we examined livestock impacts on (a) cover of plant functional types, (b) overall species composition, (c) species richness and evenness, (d) spatial species turnover within and among sites, and (e) ground litter composition and diversity.

\section{Materials and methods}

\subsection{Study area}

The study was conducted in Nahuel Huapi National Park, which is located on the eastern foothills of the Andes $\left(40^{\circ} 15^{\prime}-41^{\circ} 30^{\prime} \mathrm{S}\right)$ in north-western Patagonia, Argentina (Veblen et al., 1992). The landscape topography was carved by Quaternary glaciations, including the last glacial retreat some $14-12 \mathrm{~K} \mathrm{yr} \mathrm{BP}$. Soils are poorly developed Andisols derived from volcanic ash layers. The climate is cool temperate, with average temperatures around $8.3^{\circ} \mathrm{C}$. Mean annual precipitation decreases markedly from west to east, ranging from $\sim 3500 \mathrm{~mm} / \mathrm{yr}$ near the Andean divide to $\sim 800 \mathrm{~mm} / \mathrm{yr}$ at the woodland-steppe ecotone, some $60 \mathrm{~km}$ eastward (Barros et al., 1983; Jobbágy et al., 1995; Veblen et al., 1996). Most precipitation falls during autumn and winter (April-September), being usually sparse from October through March. Study sites were spread over a 1500$2800 \mathrm{~mm}$ precipitation gradient, and were representative of midelevation (800-900 m), broadleaved evergreen forests dominated by $N$. dombeyi (Table 1 ). This species forms monotypic, $20-30 \mathrm{~m}$ height stands; the conifer Austrocedrus chilensis occurs as subordinate canopy tree, increasing towards drier sites. Moister forests near the Andean divide are enriched with elements from the Valdivian rainforests of Chile, including Maytenus magellanica, Drimys winteri, and Weinmannia trichosperma (Veblen et al., 1996; 
Table 1

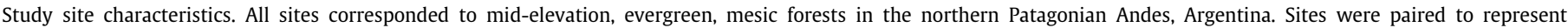
contrasting histories of livestock disturbance along a region-wide moisture gradient.

\begin{tabular}{|c|c|c|c|c|}
\hline Site name (pair) & Location/elevation & Ungulate herbivores & Climate & Canopy structure \\
\hline \multirow[t]{3}{*}{ Lago Espejo - Isla Chacal Huapi (1) } & $40^{\circ} 32^{\prime} 52^{\prime \prime} \mathrm{S}$ & \multirow[t]{3}{*}{ No livestock. Wild boar and deer trails } & MAP: $2800 \mathrm{~mm} / \mathrm{yr}$ & CC: $81 \%(4.8)$ \\
\hline & $71^{\circ} 46^{\prime} 10^{\prime \prime} \mathrm{W}$ & & MAT: $7.7^{\circ} \mathrm{C}$ & NDVI: 0.82 \\
\hline & 840 m.a.s.l. & & $\begin{array}{l}\text { PET: } 559 \mathrm{~mm} / \mathrm{yr} \\
\text { RH: } 86 \%\end{array}$ & PAR: $2 \%$ \\
\hline \multirow{3}{*}{ Lago Espejo - Península (1) } & $40^{\circ} 38^{\prime} 43^{\prime \prime} \mathrm{S}$ & \multirow{3}{*}{ Long-term livestock presence. Wild boar trails } & \multirow{3}{*}{ MAP: $2300 \mathrm{~mm} / \mathrm{yr}$} & CC: $78 \%(4.9)$ \\
\hline & $71^{\circ} 43^{\prime} 27^{\prime \prime} \mathrm{W}$ & & & NDVI: 0.81 \\
\hline & 850 m.a.s.l. & & & PAR: $5 \%$ \\
\hline \multirow[t]{3}{*}{ Lago Espejo - Margen este (2) } & $40^{\circ} 37^{\prime} 14^{\prime \prime} \mathrm{S}$ & \multirow[t]{3}{*}{ No livestock. Wild boar trails } & MAP: $2350 \mathrm{~mm} / \mathrm{yr}$ & CC: $83 \%(4.4)$ \\
\hline & $71^{\circ} 43^{\prime} 51^{\prime \prime} \mathrm{W}$ & & MAT: $7.9^{\circ} \mathrm{C}$ & NDVI: 0.81 \\
\hline & 866 m.a.s.l. & & $\begin{array}{l}\text { PET: } 563 \mathrm{~mm} / \mathrm{yr} \\
\text { RH: } 80 \%\end{array}$ & PAR: $2 \%$ \\
\hline \multirow[t]{3}{*}{ Lago Espejo - Cruce Puyehue (2) } & $40^{\circ} 41^{\prime} 32^{\prime \prime} \mathrm{S}$ & \multirow[t]{3}{*}{ Long-term livestock presence } & \multirow[t]{3}{*}{ MAP: $2000 \mathrm{~mm} / \mathrm{yr}$} & CC: $77 \%(5.9)$ \\
\hline & $71^{\circ} 42^{\prime} 02^{\prime \prime} \mathrm{W}$ & & & NDVI: 0.81 \\
\hline & 890 m.a.s.l. & & & PAR: $20 \%$ \\
\hline \multirow[t]{3}{*}{ Lago N. Huapi, Quetrihue - Mirador (3) } & $40^{\circ} 47^{\prime} 10^{\prime \prime} \mathrm{S}$ & \multirow[t]{3}{*}{ No livestock, for $>50 \mathrm{yr}$. Wild boar trails } & MAP: $1900 \mathrm{~mm} / \mathrm{yr}$ & CC: $89 \%(3.3)$ \\
\hline & $71^{\circ} 39^{\prime} 42^{\prime \prime} \mathrm{W}$ & & MAT: $8.7^{\circ} \mathrm{C}$ & NDVI: 0.83 \\
\hline & 850 m.a.s.l. & & $\begin{array}{l}\text { PET: } 582 \mathrm{~mm} / \mathrm{yr} \\
\mathrm{RH}: 76 \%\end{array}$ & PAR: $5 \%$ \\
\hline \multirow[t]{3}{*}{ Lago N. Huapi, Quetrihue - Laguna Patagüa (3) } & $40^{\circ} 50^{\prime} 16^{\prime \prime} \mathrm{S}$ & \multirow[t]{3}{*}{ Long-term livestock presence. Wild boar trails } & \multirow[t]{3}{*}{ MAP: $1850 \mathrm{~mm} / \mathrm{yr}$} & CC: $83 \%(6.1)$ \\
\hline & $71^{\circ} 36^{\prime} 43^{\prime \prime} \mathrm{W}$ & & & NDVI: 0.84 \\
\hline & 890 m.a.s.l. & & & PAR: $19 \%$ \\
\hline \multirow[t]{3}{*}{ Lago Gutierrez - Playa Muñoz (4) } & $41^{\circ} 12^{\prime} 48^{\prime \prime} \mathrm{S}$ & \multirow[t]{3}{*}{ No livestock, for $>50 \mathrm{yr}$. Wild boar trails } & MAP: $1900 \mathrm{~mm} / \mathrm{yr}$ & CC: $81 \%(3.3)$ \\
\hline & $71^{\circ} 26^{\prime} 07^{\prime \prime} \mathrm{W}$ & & MAT: $8.7^{\circ} \mathrm{C}$ & NDVI: 0.74 \\
\hline & 920 m.a.s.l. & & $\begin{array}{l}\text { PET: } 583 \mathrm{~mm} / \mathrm{yr} \\
\mathrm{RH}: 65 \%\end{array}$ & PAR: $6 \%$ \\
\hline \multirow[t]{3}{*}{ Lago Mascardi - Arroyo Lloconto (4) } & $41^{\circ} 21^{\prime} 36^{\prime \prime} \mathrm{S}$ & \multirow[t]{3}{*}{ Long-term livestock presence. Wild boar trails } & \multirow[t]{3}{*}{ MAP: $1500 \mathrm{~mm} / \mathrm{yr}$} & CC: $83 \%(2.4)$ \\
\hline & $71^{\circ} 34^{\prime} 05^{\prime \prime} \mathrm{W}$ & & & NDVI: 0.71 \\
\hline & 820 m.a.s.l. & & & PAR: $10 \%$ \\
\hline \multirow[t]{3}{*}{ Lago Traful - Isla (5) } & $40^{\circ} 35^{\prime} 36^{\prime \prime} \mathrm{S}$ & \multirow[t]{3}{*}{ No livestock. Wild boar trails } & MAP: $1600 \mathrm{~mm} / \mathrm{yr}$ & CC: $76 \%(4.5)$ \\
\hline & $71^{\circ} 29^{\prime} 56^{\prime \prime} \mathrm{W}$ & & MAT: $9.5^{\circ} \mathrm{C}$ & NDVI: 0.75 \\
\hline & 818 m.a.s.l. & & $\begin{array}{l}\text { PET: } 601 \mathrm{~mm} / \mathrm{yr} \\
\text { RH: } 67 \%\end{array}$ & PAR: $14 \%$ \\
\hline \multirow[t]{3}{*}{ Lago Traful - Península (5) } & $40^{\circ} 35^{\prime} 43^{\prime \prime} \mathrm{S}$ & \multirow[t]{3}{*}{ Long-term livestock presence. Wild boar trails } & \multirow[t]{3}{*}{ MAP: $1600 \mathrm{~mm} / \mathrm{yr}$} & CC: $76 \%(7.7)$ \\
\hline & $71^{\circ} 29^{\prime} 53^{\prime \prime} \mathrm{W}$ & & & NDVI: 0.77 \\
\hline & 814 m.a.s.l. & & & PAR: $22 \%$ \\
\hline
\end{tabular}

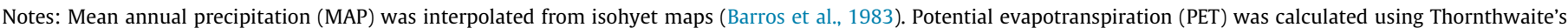

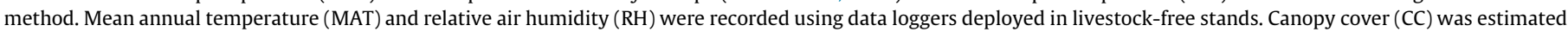

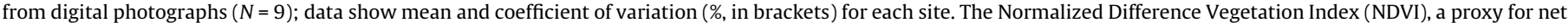

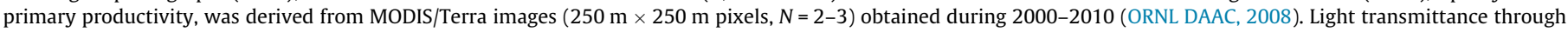

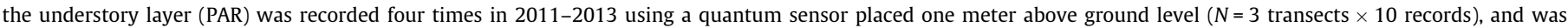
expressed as percentage of PAR measured in nearby open areas.

Ezcurra and Brion, 2005). Understory communities are often dominated by the tall bamboo Chusquea culeou, but also comprise several small tree and shrub species, and a sparse ground layer of forbs, grasses and ferns.

Native ungulate densities have been extremely low throughout the region since the arrival of European settlers in the XIX century (Veblen et al., 1996; Vázquez, 2002). The small cervid Pudu pudu was probably the most abundant browser in pre-colonial forests; larger herbivores such as the camelids Hippocamelus bisulcus and Lama guanicoe typically use more open habitats (Vázquez, 2002). Domestic cattle, sheep and horses were introduced to the Nahuel Huapi area during the 1800s (Veblen et al., 1992, 1996). Other exotic ungulates such as red deer (Cervus elaphus) and wild boar (Sus scrofa) were later introduced for game and expanded rapidly. During the mid-1900s, livestock farming became a major activity for landowners, small farmers and settlers. When the National Park was created in 1934, farming permits were granted that allowed for regulated animal stocks (Veblen et al., 1992). Lack of federal control and poor management of cattle populations, which were left to roam freely (unfenced) within native forests, imply that any assessment of current stocking rates is only tentative. Animal densities for the watersheds in which the study sites were located would be under 0.1 cows/ha (Lauría Sorge and Romero, 1999). It is now estimated that domestic and feral livestock occupy over 50\% of the total Park area, and although efforts have been made to reduce, if not eradicate all unmanaged cattle, at present this seems unfeasible for socio-economic, cultural, and logistic reasons.

\subsection{Site selection and environmental conditions}

In late summer 2010, we selected 10 mature forest stands ( $N$. dombeyi $>150-200$ years old) scattered along a $90 \mathrm{~km}$, NW-SE transect (Table 1). Sites were chosen to represent two contrasting land-use conditions in terms of long-term presence/absence of domestic cattle (Table 1). In this area, the very existence of oldgrowth forests undisturbed by domestic herbivores is extremely rare (Veblen et al., 1989, 1992; Raffaele et al., 2007). Therefore, our design was constrained by the availability and geographic location of livestock-free sites. Firstly, we selected five forest sites where access to livestock was impeded by natural barriers (watersheds surrounded by steep ridges and lake islands) or restricted by Park managers. The 'unbrowsed' stands remained free of livestock disturbance for at least 50 years, and three of them were never used for cattle ranching (Table 1$)$. These sites were located at varying distances from the continental divide $\left(72^{\circ} \mathrm{W}\right)$, and were therefore expected to receive different amounts of precipitation (Barros et al., 1983; Jobbágy et al., 1995). Secondly, for each livestock-free site, we selected the nearest forest site that could be confidently determined as being regularly used by livestock for the last 50 years or more. Further, paired sites should be as similar as 
possible with regard to mean annual precipitation, as determined from regional isohyet maps (Table 1; Barros et al., 1983). However, because such maps are drawn at a much coarser spatial resolution than the average distance between paired sites $(9 \mathrm{~km})$, differences in annual precipitation between browsed and unbrowsed sites (see Table 1 ) should only be taken as approximate. The site history of cattle utilization was checked with local farmers and park rangers, and was further confirmed by the presence of animal trails, fecal pats and browsing signs. We also ensured that paired sites were similar with regard to overstory cover, stand age, elevation, disturbance history, and presence of wild ungulates (red deer, boar). The study sites did not burn for at least 80-100 years.

To better represent environmental differences along the precipitation gradient, we calculated a Moisture index (M) combining mean annual precipitation (MAP, $\mathrm{mm} / \mathrm{yr}$ ) and potential evapotranspiration (PET, $\mathrm{mm} / \mathrm{yr}$ ) data, where $\mathrm{M}=\mathrm{MAP} / \mathrm{PET}$ (Knapp and Smith, 2001; Table 1). Paired sites were attributed a single M score using their average MAP. We calculated PET from temperature data using Thornthwaite's formula. Mean daily temperature and relative air humidity (\%) were recorded using HOBO data loggers (Onset Computer Corp., Mass.) deployed in each of the livestockfree stands between January 2011 and December 2012. Mean temperatures increased by $1.8^{\circ} \mathrm{C}$ from the wettest to the driest forests, while air humidity decreased from $86 \%$ to $67 \%$ (Table 1 ). Temperature data were used to obtain a single PET value for each pair of sites, assuming that latitudinal differences between paired sites could have produced $<7 \%$ change in MAT. Overall, the M index ranged 2.7-4.6 along the study gradient.

In addition, for each study site, we obtained the Normalized Difference Vegetation Index (NDVI) from MODIS/Terra satellite imagery (ORNL DAAC, 2008), where NDVI is a measure of canopy photosynthetic activity that is commonly used as a proxy for net primary productivity (Pettorelli et al., 2005). We combined pixel grids $(250 \mathrm{~m} \times 250 \mathrm{~m})$ with Google Earth images and for each site we selected 2-3 pixels located at similar elevations and with the lowest possible cover of features other than mature forest (water, roads, burned areas, etc.). Annual NDVI data were collected for the period 2000-2010. As expected, NDVI was nearly 15\% higher in wetter than in drier forests, while paired browsed and unbrowsed sites had similar NDVI values (Table 1$)$. We also measured the canopy cover for each site using digital photographs $(N=9)$ processed with CobCal software (Ferrari et al., 2008). Overstory cover averaged $81 \pm 4 \%$ and did not differ between stands with contrasting grazing histories (linear mixed-effect model, $F_{1,6}=0.87$, $P=0.39$ ) or differing habitat moisture $\left(F_{1,6}=0.08, P=0.79\right.$; Table 1$)$. We also found no significant difference across sites in terms of within-stand canopy structure (spatial CV\% of canopy cover, $P>0.10$ ). However, light levels beneath the understory layer decreased from dry to wet forest sites (lme, $F_{1,6}=5.47, P=0.058$ ), and were significantly higher in cattle-browsed than in cattlefree stands $\left(15.1 \pm 3.3 \%\right.$ vs. $5.7 \pm 2.3 \% ; F_{1,6}=6.75, P=0.041$; see Table 1). Lastly, total soil carbon and nitrogen contents, and soil $\mathrm{C}: \mathrm{N}$ ratios did not vary significantly among forest sites, whereas soil gravimetric water increased along the study gradient $(P=0.02)$ but did not differ between paired sites (see Appendix Table A1).

\subsection{Vegetation sampling}

Sampling was performed during early April 2010 by placing three, equally oriented $50 \mathrm{~m}$-long transects per site. Transects were located near the center of a 5-ha homogeneous stand, allowing for wide buffer zones from the forest edges. In each stand, the first transect was started at a random point, while the other two followed the same direction and were placed at $50-200 \mathrm{~m}$ from each other, depending on the shape and size of the site (c. 10-15 ha). We measured the projected ground cover of understory plants up to $\sim 3 \mathrm{~m}$ height using five, $2 \mathrm{~m} \times 2$ m quadrats, regularly spaced at $10 \mathrm{~m}$ along each transect (15 quadrats per stand). This plot size was adequate for the modal size of common sub-canopy woody species, with a projected crown area typically smaller than $4 \mathrm{~m}^{2}$. As a result, the average sample plot across all sites included 5-12 species (see Appendix Fig. A2). Percentage species cover, including ferns and mosses, was visually estimated to the nearest $5 \%$ and agreed between two observers. Total cover could exceed $100 \%$ due to the multi-layered structure of the understory. All vascular plants were identified to species following Ezcurra and Brion (2005).

We sampled the ground litter layer by placing a sub-quadrat $\left(0.25 \mathrm{~m}^{2}\right)$ at the center of each cover quadrat. All fallen leaves within the sub-quadrat were collected in plastic bags, air dried and stored until processing. In the laboratory, litter was sorted into $N$. dombeyi (dominant tree) and 'other species' leaves, which included litter from subordinate woody species and herbs; other plant parts (e.g. twigs) were discarded. We recorded the number of species present in the litter layer and their percentage dry mass, after pooling over samples within stands. Litter samples were oven dried $\left(60^{\circ} \mathrm{C}\right)$ and weighed $(0.01 \mathrm{~g})$ to determine leaf litter mass $\left(\mathrm{g} / \mathrm{m}^{2}\right)$ per stand.

\subsection{Data analyses}

Plant species were classified by functional type into trees, shrubs and herbs (i.e. forbs, grasses and ferns); bamboo (C. culeou) was considered separately (Ezcurra and Brion, 2005). Woody species (shrubs and trees) were further sub-divided into species with hard or spiny leaves vs. species with soft leaves and no spines (Bryant et al., 1983; Díaz et al., 2006). This grouping was validated by measuring several other leaf traits as part of a larger project (M.V. Piazza, unpublished data). Patterns in total and functional type cover were examined through linear mixed-effect models using the 'lme' function of the 'nlme' package in $\mathrm{R}$ version 2.13.0 (Pinheiro et al., 2011; R Development Core Team, 2011). The effects of livestock herbivory (two levels: present vs. absent) and habitat moisture (five levels or site pairs) were tested through a random intercept model, where herbivory $(\mathrm{H})$ and moisture index $(\mathrm{M})$ were coded as discrete and continuous fixed predictors, respectively. A nested random effects model structure was defined to account for the pairing of sites along the $\mathrm{M}$ gradient and for transects nested in sites (Pinheiro and Bates, 2000). Sample quadrats were averaged within transects before analysis. Model significance was tested by sequential fitting of main effects and their interaction using the function 'anova' in the 'nlme' pakage (Pinheiro et al., 2011). Where variance heterogeneity affected the estimation of herbivore effects, models were ran with a constant variance structure using the function 'varIdent' (Pinheiro and Bates, 2000).

We conducted non-metric multidimensional scaling (NMDS) to examine patterns in understory species composition using the species' relative cover (total $=61 \mathrm{spp}$ ). Ordination analysis was performed at the transect scale to account for compositional variation within sites, relative to differences among sites (total $=30$ transects). A three-dimensional solution was defined after selecting the lower-stress dissimilarity function of the 'vegan' package in $\mathrm{R}$ (Oksanen et al., 2011). The relationship between sample scores and the underlying moisture gradient was depicted by fitting the $\mathrm{M}$ index vector through ordination space using the 'envfit' function (Oksanen et al., 2011). Pairwise floristic differences between stands with and without livestock were computed using Bray-Curtis distances. To evaluate the observed differences in species composition, we used linear mixed-effects models (nlme package in $\mathrm{R}$ ) to determine whether sample scores on the first two NMDS dimensions varied significantly according to livestock 
presence, habitat moisture $(\mathrm{M})$ or both. These models considered the hierarchical structure of the design with transects nested in sites, as described before (Pinheiro and Bates, 2000). We expected an interaction between livestock and habitat moisture, so that floristic differences between paired stands would increase along the moisture gradient (see Chase et al., 2000; Lezama et al., 2014).

Plant species diversity was evaluated at the stand scale ( $\alpha$-diversity) using: (i) species richness $(S)$, the mean number of species per transect; (ii) Shannon's effective diversity $\left(N_{1}=\mathrm{e}^{H^{\prime}}\right.$, where $H^{\prime}$ is the Shannon-Weiner diversity index), which represented the number of common species per transect; and (iii) species evenness $\left(E=\mathrm{e}^{H^{\prime}} / S\right)$, the ratio between effective diversity and maximum diversity (Hill, 1973; Magurran, 1988). These indices were calculated by taking the mean relative cover of all species encountered over the five quadrats placed along a transect, and thus reflected species numbers and abundances over a $20-\mathrm{m}^{2}$ sample area (Crist and Veech, 2006). Domestic herbivores were predicted to increase plant diversity, especially in moister, more productive forests (Proulx and Mazumder, 1998; Hillebrand et al., 2007). To evaluate the scale-dependency of $\alpha$-diversity results, we generated species accumulation curves for each site by computing the randomized mean cumulative species richness for sample sizes ranging 1-15 quadrats (99 permutations; Oksanen et al., 2011). Litter richness, effective diversity and evenness were similarly computed, except that the litter samples were pooled over each forest stand.

We expected livestock presence to reduce spatial heterogeneity in species composition within stands ( $\beta$-diversity, local scale), due to increased dominance by herbivore-resistant species (Olff and Ritchie, 1998; Adler et al., 2001). Conversely, low herbivore densities typical of the study forests may lead to increased heterogeneity in understory composition (Adler et al., 2001). Furthermore, domestic herbivores might increase community turnover at a regional scale, by favoring different species in drier and moister habitats (Coomes et al., 2009). To test these predictions, we computed $\beta$-diversity at two scales using the additive model, $\beta=\gamma-\alpha$ (Magurran, 1988; Anderson et al., 2011). For 'local' $\beta$ diversity, $\gamma$ was the total species number per 50-m transect, and $\alpha$ was the mean richness per quadrat within each transect. For 'regional' $\beta$ diversity, $\gamma$ was the total number of species found in the presence (52 spp) or absence (39 spp) of domestic herbivores over the entire moisture gradient, and $\alpha$ was the mean species number per transect in a given a stand. Statistical differences in species richness, Shannon's diversity, evenness ( $\alpha$-diversity), and species turnover ( $\beta$-diversity) at local and regional scales were examined through linear mixed-effect models, with livestock presence, habitat moisture and their interaction as fixed effects, as described before (Pinheiro et al., 2011; R Development Core Team, 2011). Linear models for litter diversity only tested the effect of livestock ( $N=5$ pairs of sites), since we lacked replicates for litter richness and composition within stands.

\section{Results}

\subsection{Understory cover and functional type abundances}

Long-term use by cattle significantly altered understory structure in $N$. dombeyi forests (see Appendix, Table A2). On average, domestic herbivores reduced understory cover to less than half $(48 \pm 17 \%$, mean \pm SD) the cover in livestock-free sites (112 $\pm 20 \%)$, a pattern observed throughout the moisture gradient (Fig. 1). In addition, the vegetation of browsed stands exhibited greater spatial heterogenity in total cover than that of unbrowsed stands $\left(\mathrm{H}: F_{1,6}=7.37, P=0.035\right)$. The average $\mathrm{CV}$ for understory cover was $54.9 \%( \pm 5.4)$ and $35.7 \%( \pm 4.7)$, in browsed and

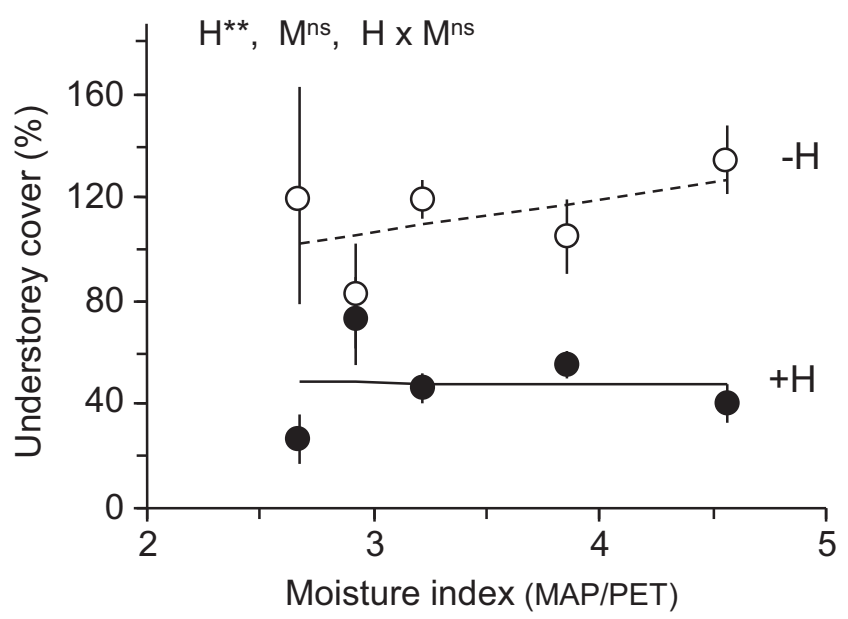

Fig. 1. Total understory cover in Nothofagus dombeyi forests with long-term presence $(+\mathrm{H}$, solid symbols) or absence $(-\mathrm{H}$, empty symbols) of domestic herbivores along a regional moisture gradient. Moisture index $(\mathrm{M})=$ mean annual precipitation (MAP)/potential evapotranspiration (PET). Symbols show means \pm SE $(N=3$ transects). Asterisks denote significant effects from herbivory $(\mathrm{H})$ and habitat moisture (M): ${ }^{* *} P<0.01,{ }^{\text {ns }} P>0.10$.

unbrowsed stands, respectively. This effect was consistent throughout the moisture gradient $\left(\mathrm{H} \times \mathrm{M}: F_{1,6}=0.05, P=0.84 ; \mathrm{M}\right.$ : $F_{1,6}=3.33, P=0.12$ ).

These effects accompanied a 70\% decrease in woody species cover (trees + shrubs, $P=0.0017$, Table A2) in cattle browsed, relative to unbrowsed sites. Long-term livestock presence led to marked reductions in tree (65\%), shrub (25\%) and bamboo (55\%) cover, irrespective of habitat moisture (Fig. $2 \mathrm{a}-\mathrm{c}$ ). In addition, livestock presence had a significantly negative effect on the cover of soft-leaved woody species, which decreased by $74 \%$ in cattle browsed, relative to unbrowsed sites (Fig. 2e). There was no difference in hard-leaved woody cover associated with either livestock presence or habitat moisture (Fig. 2f). Although the absolute cover of ground herbs did not change with livestock presence (Fig. 2d, Table A2), their relative cover increased from $15 \%$ in unbrowsed sites to $41 \%$ in browsed sites ( $\mathrm{H}: F_{1,6}=6.35, P=0.045 ; \mathrm{H} \times \mathrm{M}$ : $F_{1,6}=1.38, P=0.29$ ). In general, functional group abundances did not reflect a significant herbivory $\times M$ interaction (Fig. 2, Table A2).

\subsection{Understory species composition}

We found substantial floristic differences between paired sites (Bray-Curtis distances $=67-100 \%$ ). Non-metric ordination showed that compositional differences between cattle browsed and unbrowsed sites, which are reflected on the first NMDS axis (sample scores lme, $F_{1,6}=17.32, P=0.006$ ), tended to increase with habitat moisture (Fig. 3 ). This pattern was shown by a significant $\mathrm{H} \times \mathrm{M}$ interaction $\left(F_{1,6}=7.99, P=0.03\right)$ for sample scores on the first ordination axis. Further, while species composition varied along the moisture gradient (lme, NMDS-1: $F_{1,6}=9.63, P=0.021$; NMDS-2: $\left.F_{1,6}=5.56, P=0.056\right)$, region-wide floristic differences were greater across livestock-free, unbrowsed forests (Fig. 3). Livestock exerted a smaller impact on the species composition of drier forests, in part because within-site heterogeneity at the transect scale (mean Bray-Curtis distance $=25-80 \%$ ) decreased toward moister forests $\left(F_{1,6}=18.93, P=0.005\right.$; see Fig. 3$)$.

The greater floristic distances between browsed and unbrowsed sites found in moister forests reflected both a decrease in the number of shared species and the increased presence of exclusive species along the moisture gradient, especially in cattle browsed sites (Appendix, Fig. A1). From a total of 61 species recorded in this 

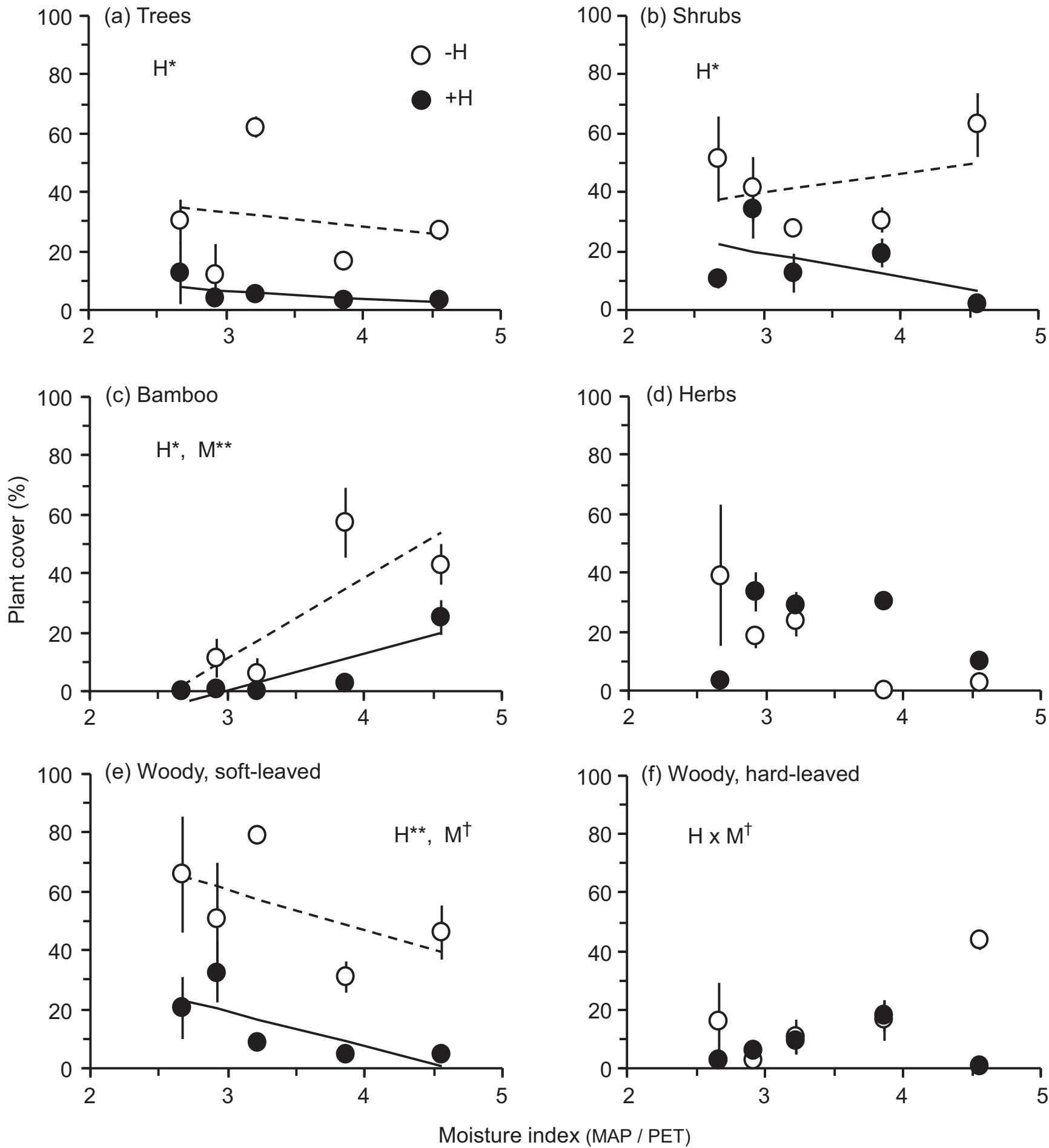

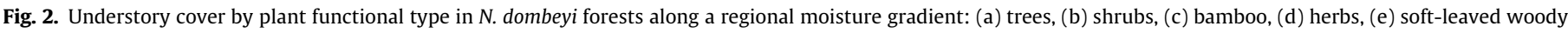

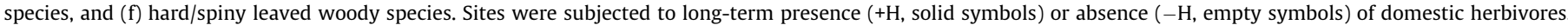
Symbols show means \pm SE $(N=3)$. Asterisks denote effects from herbivory $(\mathrm{H})$ and habitat moisture $(\mathrm{M}):{ }^{* *} P<0.01,{ }^{*} P<0.05,{ }^{\dagger} P<0.10$.

study, nearly $50 \%$ (30 spp) were shared between browsed and unbrowsed sites, 22 species were exclusive to browsed stands (42\%, mostly herbs), while only 9 species were exclusive to unbrowsed stands (23\%, mostly woody). Species typical of cattle browsed stands included forbs (e.g. Adenocaulon chilense, Osmorhiza chilensis, Prunella vulgaris), spiny shrubs (Berberis spp.) and a small fern (Blechnum penna-marina). Livestock-free stands were characterized by several woody species, including Desfontainea spinosa, Myrceugenia chrysocarpa, Maytenus magellanica Buddleja globosa and Dasyphyllum diacantoides (see Appendix, Table A3).

There was a clear tendency for cattle disturbance to increase the number of exotic species per site $\left(F_{1,6}=5.1, P=0.065\right)$, regardless habitat moisture $\left(\mathrm{H} \times \mathrm{M}: F_{1,6}=0.21, P=0.55\right)$. One third of the herbs found in cattle browsed sites were exotic, yet they were generally rare in terms of richness $(1.8 \pm 0.96 \mathrm{spp} / \mathrm{site})$ and ground cover $(0.6 \pm 0.45 \%)$. 


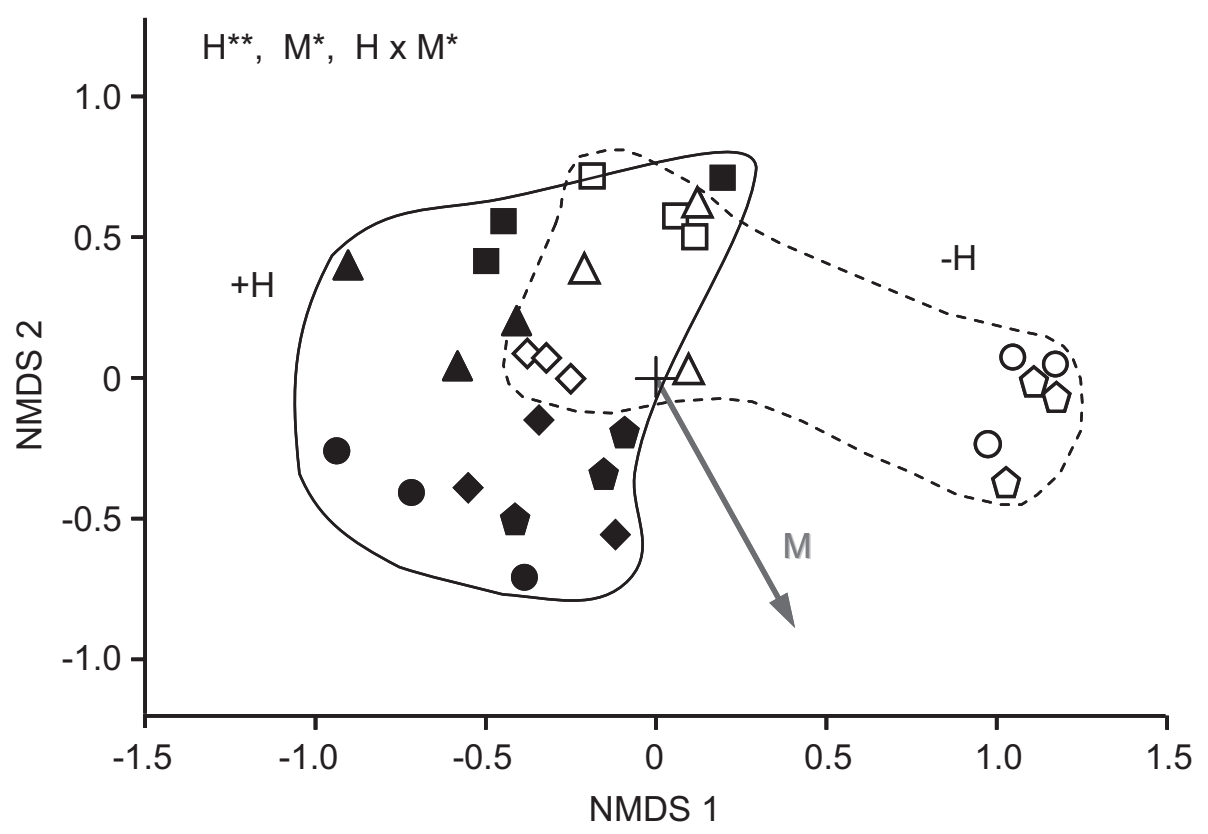

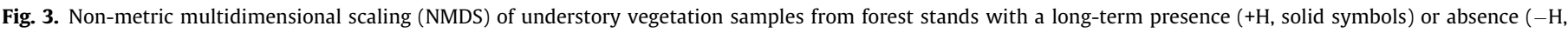

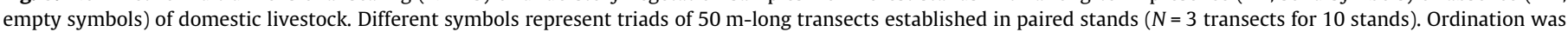

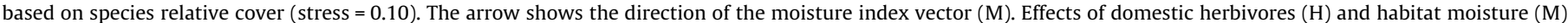
from a linear mixed-effects model of sample scores on axis 1 (transects nested in stands): ${ }^{* *} P<0.01,{ }^{*} P<0.05$.

\subsection{Species $\alpha$-diversity}

Livestock herbivory did not consistently affect species richness along the moisture gradient (Fig. 4a; see Appendix, Table A4). We only detected significant differences for two pairs of sites, where richness increased at $\sim 5 \mathrm{spp} /$ transect in browsed, relative to unbrowsed stands (Student's $t=2.9$ and $4.1, d f=4$, both $P<0.05$ ). The other paired sites did not differ with regard to plant richness $(t=0.89-2.01, d f=4, P>0.1)$. These patterns did not depend on the sampling intensity, as shown by species accumulation curves drawn within sites (Appendix, Fig. A2). The average 'effective' diversity was also not affected by livestock presence (Fig. 4b, Table A4). However, forest understories subjected to livestock browsing showed a highly significant decrease (30\%) in species evenness, relative to their livestock-free counterparts (Fig. 4c). There were no clear trends in understory richness, diversity or evenness along the moisture gradient (Fig. 4, Table A4).

\subsection{Spatial species turnover ( $\beta$-diversity)}

On average, livestock presence did not consistently affect within-site community heterogeneity but interacted with habitat moisture to increase $\beta$-diversity in the moister forest stands (Fig. 5a, Table A4). At the regional scale, however, browsed forests exhibited lower species turnover across sites than livestock-free unbrowsed forests, a pattern that was consistent throughout the moisture gradient (Fig. 5b). Thus, long-term use by cattle increased the proportional representation of the regional species pool within individual forest stands.

\subsection{Litter composition and diversity}

Total leaf litter mass tended to decrease with increasing habitat moisture, but did not differ between cattle browsed and unbrowsed stands (Fig. 6a). Likewise, litter accumulation by the dominant canopy tree $N$. dombeyi was not affected by livestock presence or habitat moisture (see Appendix, Table A5).
Importantly, however, long-term use by cattle decreased by $56 \%$ the average proportional contribution of subordinate species to the leaf-litter layer (Fig. 6b, Table A5).

Although litter species richness did not change with livestock presence (litter $S,+\mathrm{H}=12.6 \pm 0.6 v s$. $-\mathrm{H}=15.0 \pm 1.26$; see Appendix, Table A6), the litter effective diversity was $42 \%$ lower in browsed than in unbrowsed stands (litter $\mathrm{e}^{H^{\prime}},+\mathrm{H}=2.32 \pm 0.13 v$ s. $-\mathrm{H}=4.12 \pm 0.44 ; P=0.005)$. This pattern resulted from a significant decrease (32\%) in litter species evenness under livestock herbivory, compared to that in livestock-free sites (litter $E$, $+\mathrm{H}=0.19 \pm 0.02$ vs. $-\mathrm{H}=0.27 \pm 0.02, P=0.01$; Table A6). The fact that such differences in litter diversity disappeared $(P>0.10)$ after excluding $N$. dombeyi leaves (see Table A6) indicated that livestock presence led to greater dominance of the litter layer by $N$. dombeyi leaves.

\section{Discussion}

Our results show that domestic cattle strongly affected understory structure and composition in $N$. dombeyi forests of the northern Patagonian Andes. Based on five paired sites distributed over a broad moisture gradient, we found that livestock impacts on native forest understories involved changes in ground cover, functional composition and species evenness, which were largely independent of habitat moisture. We observed, however, a greater effect from long-term cattle browsing on the species composition of wetter forests, a pattern predicted by grazing models that emphasize the role of plant growth-defense tradeoffs along resource gradients (Coley et al., 1985; Leibold et al., 1997). Moreover, changes in standing vegetation associated with livestock presence also affected the litter layer composition, with potential consequences for soil ecosystem functions (Pastor and Cohen, 1997; Wardle and Bardgett, 2004). Overall, beech forest understories in Nahuel Huapi National Park appear to have switched to a degraded state maintained by traditional ranching activities. Thus, novel approaches to cattle management would be required for effective forest recovery and conservation. 

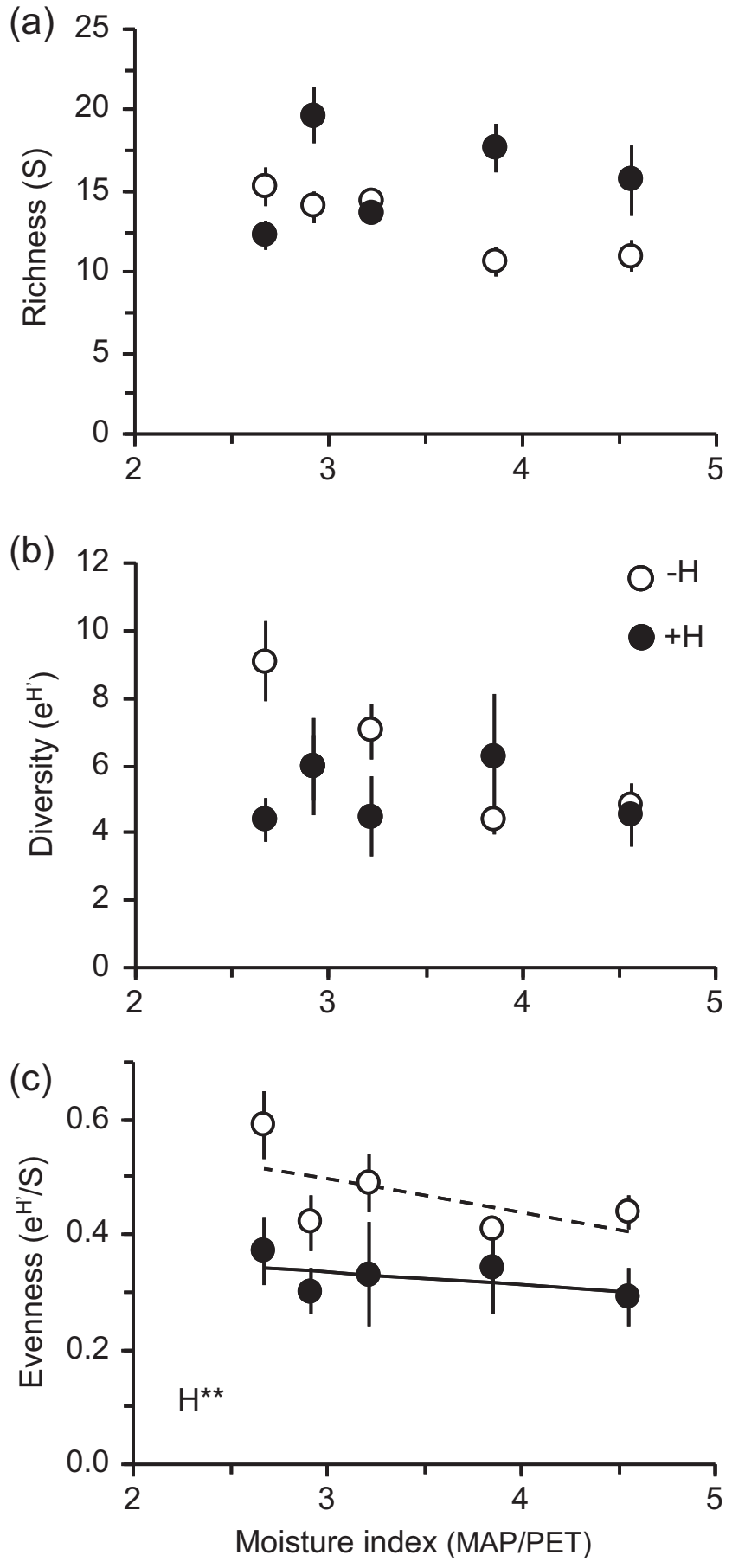

Fig. 4. Understory species $(\alpha)$ diversity in Nothofagus dombeyi forests with a longterm presence $(+\mathrm{H}$, solid symbols) or absence $(-\mathrm{H}$, empty symbols) of domestic cattle along a regional moisture gradient: (a) richness ( $S=$ species no.), (b) effective diversity $\left(\exp H^{\prime}\right)$, and (c) evenness $\left(E=\mathrm{e}^{H} / S\right.$ ). Symbols show means $\pm \mathrm{SE}$, for diversity measures obtained by pooling over five, $4-\mathrm{m}^{2}$ quadrats per transect $(N=3)$. Asterisks denote a significant herbivory $(\mathrm{H})$ effect: ${ }^{* * *} P<0.01$.

\subsection{Livestock effects on understory community structure}

Habitat use by cattle altered forest community structure by inducing a generalized decrease in understory cover through the moisture gradient (Figs. 1 and 2). These results highlight the vulnerable nature of the regional flora when confronted with chronic herbivory from introduced ungulates (Veblen et al., 1989, 1992; Vázquez, 2002). Several sub-canopy trees and soft-leaved shrubs

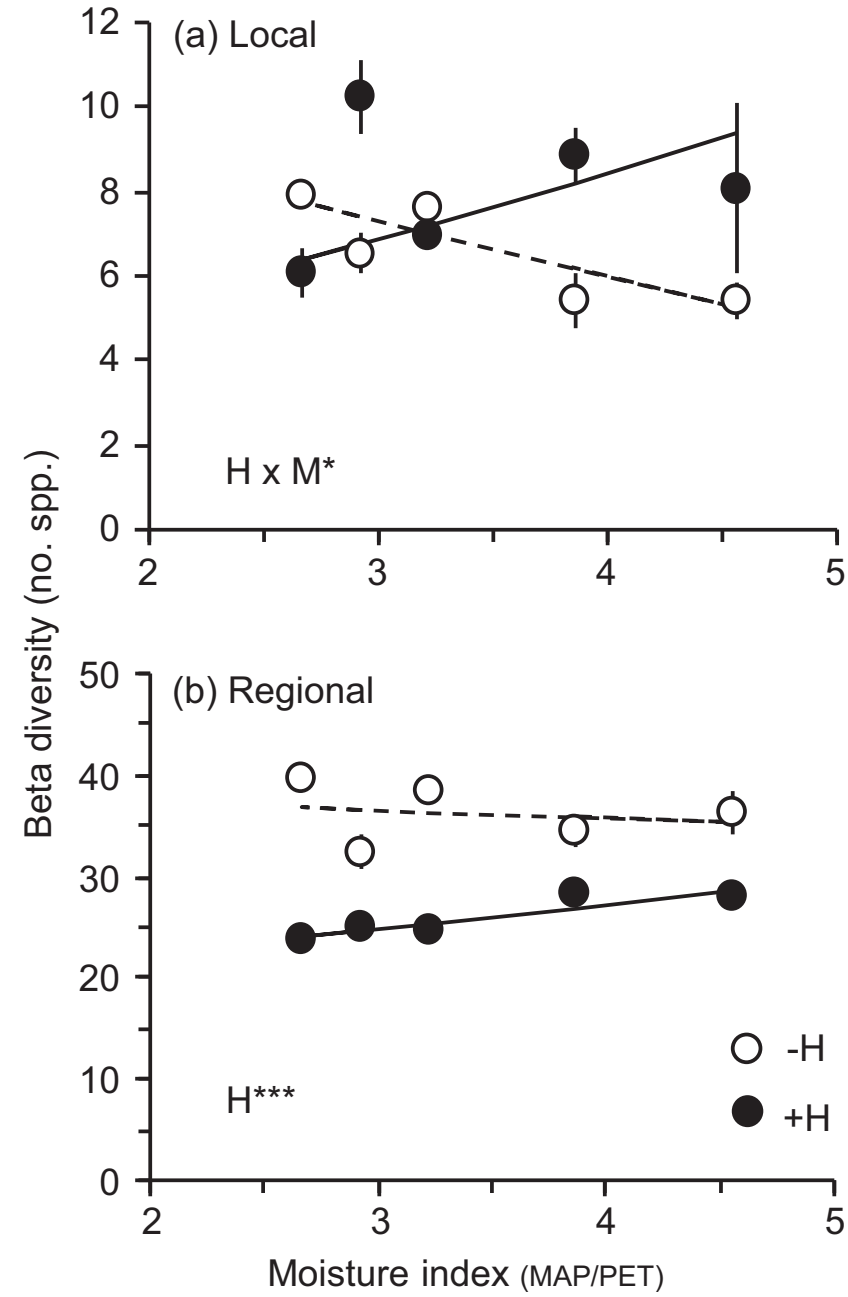

Fig. 5. Spatial species turnover ( $\beta$ diversity) for understory communities in Nothofagus dombeyi forests with long-term presence $(+\mathrm{H}$, solid symbols) or absence $(-\mathrm{H}$, empty symbols) of domestic cattle along a regional moisture gradient. Beta diversity $(\beta=\gamma-\alpha)$ was estimated at two scales: (a) local stand, where $\gamma$ and $\alpha$ were total and mean species number per transect and quadrat, respectively; and (b) regional, where $\gamma$ was the cumulative richness in $-\mathrm{H}(=39)$ or $+\mathrm{H}(=52)$ sites, and $\alpha$ was the total species number per transect within sites. Symbols show means $\pm \mathrm{SE}$ $(N=3)$. Asterisks denote effects of herbivory $(\mathrm{H})$ and habitat moisture $(\mathrm{M})$ : ${ }^{* * *} P<0.001,{ }^{*} P<0.05$

that dominated livestock-free sites markedly decreased under cattle browsing (Fig. 2, Table A3). Still, neither the hard-leaved/spiny shrubs nor a diverse group of low-growing herbs increased their absolute cover in cattle browsed stands (Fig. $2 \mathrm{~d}$ and e). This finding appears to be consistent with the broad diet consumed by cattle in these forests, which includes different functional types depending on the season (Vila and Borrelli, 2011). In contrast, studies in other temperate forests invoked competitive release from selective herbivory as a major driver of community changes induced by wild ungulates (Randall and Walters, 2011; Hegland et al., 2013; Suzuki et al., 2013). The lack of community-level compensation to cattle disturbance suggests that local environmental conditions may have constrained the initial abundance and subsequent response of herbivore-resistant species (Augustine and McNaughton, 1998; Mason et al., 2010). Light availability can be strongly limiting for plant growth and recruitment in Patagonian beech forests (Veblen et al., 1996), while spiny shrubs and ground-layer herbs and ferns typically become dominant in treefall gaps and after large-scale disturbances (Veblen et al., 1989; Raffaele et al., 2011). Hence, it is possible that reduced light levels 

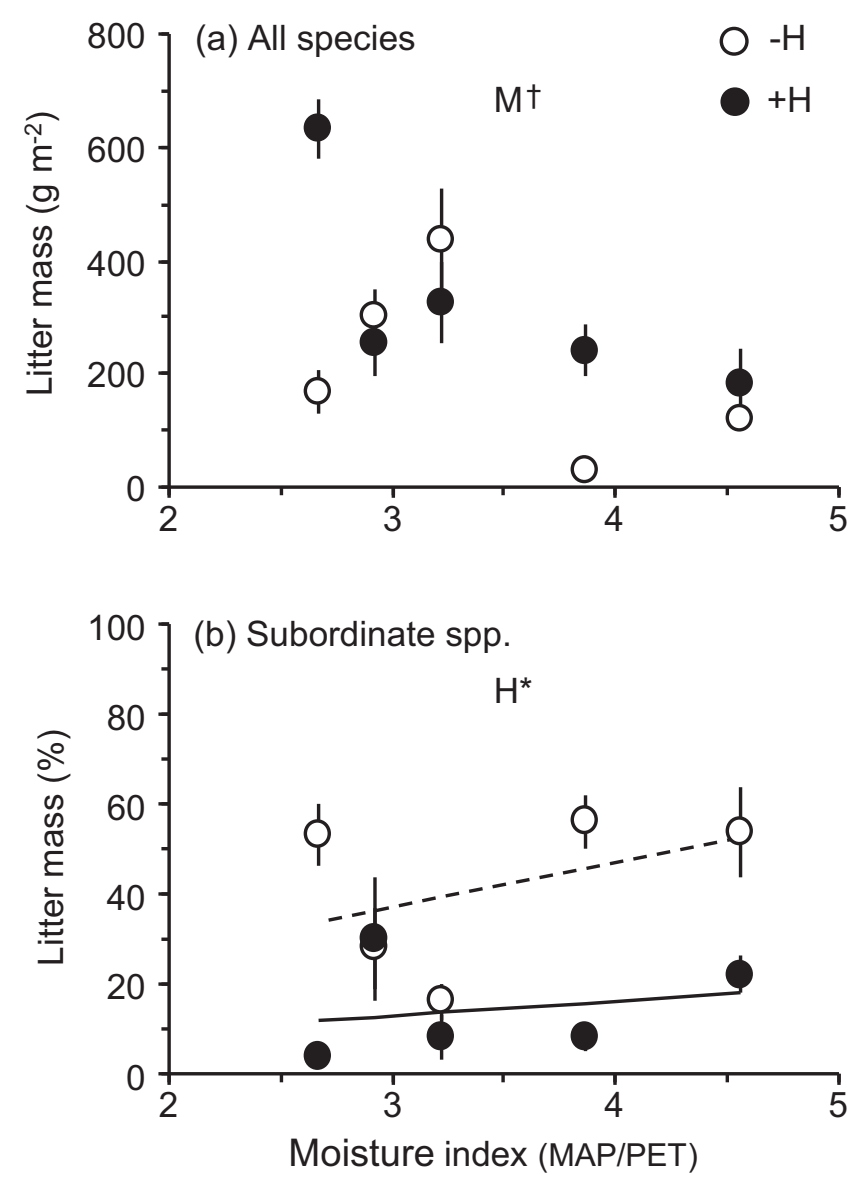

Fig. 6. Leaf litter biomass in Nothofagus dombeyi forests with long-term presence $(+\mathrm{H}$, solid symbols) or absence $(-\mathrm{H}$, empty symbols) of domestic herbivores along a regional moisture gradient. (a) total leaf litter mass $\left(\mathrm{g} \mathrm{m}^{-2}\right)$, and (b) percentage of total litter mass for species other than the dominant tree $N$. dombeyi. Symbols show means $\pm \mathrm{SE}(N=3)$. Asterisks denote effects of herbivory $(\mathrm{H})$ and habitat moisture (M): ${ }^{*} P<0.05,{ }^{\dagger} P<0.10$.

under closed $N$. dombeyi canopies (Table 1 ) precluded the compensatory response of browsing-resistant plant types.

The structural simplification of understory communities attributed to cattle disturbance was noteworthy. Livestock drastically altered the forest physiognomy by shifting the pattern of functional group dominance along the moisture gradient (see Appendix, Fig. A3). Livestock-free understories varied from dense layers of soft-leaved shrubs with a patchy herbaceous carpet in the drier forests, to nearly continuous, complex woody thickets with increasing bamboo dominance in the wetter forests. On the other hand, heavily browsed stands had a sparse woody layer in the drier forests, which gave way to a uniform herbaceous ground layer with few hard-leaved shrubs and small bamboo patches toward wetter sites (Figs. 2 and A3). These changes in functional type composition would reflect not only differential susceptibility to cattle herbivory, but also the influence of local environmental conditions on plant performance (Krueger et al., 2009; Randall and Walters, 2011). We observed that structural changes associated with cattle were most pronounced in the wetter forests, where dominance by the palatable bamboo $C$. culeou and several woody species was suppressed by heavy browsing (Veblen et al., 1992; Raffaele et al., 2007). Many such species possess re-sprouting underground organs or spiniscent shoots (Ezcurra and Brion, 2005), which can provide resistance to native ungulates (Vázquez, 2002), but may be inadequate to cope with repeated damage from domestic herbivores in light-limited environments (Haukioja and Koricheva, 2000; Hanley et al., 2007; Mason et al., 2010).
We found that understory species composition diverged between cattle browsed and unbrowsed stands toward the moister end of the study gradient. In contrast, in drier forest sites, livestock-induced changes in vegetation structure were paralleled by more diffuse compositional differences between paired sites (Figs. 3 and A1). These results are consistent with the hypothesis that the magnitude of grazing/browsing effects on plant community composition should increase along habitat moisture or productivity gradients (Milchunas et al., 1988; Chase et al., 2000). The idea that 'top-down' consumer control over vegetation attributes increases along resource gradients had been tested primarily in grasslands and aquatic systems (Milchunas and Lauenroth, 1993; Proulx and Mazumder, 1998; Hillebrand et al., 2007; Lezama et al., 2014), but remained rarely addressed in forested landscapes (Randall and Walters, 2011; see Kuijper et al., 2015, for an updated review).

Two mechanisms might have contributed to the observed interaction of livestock disturbance with habitat moisture in shaping understory species composition. First, in the absence of cattle, wetter forests were dominated by highly palatable, bamboo and woody species, which thrive in the more shaded environment of Nothofagus rainforests (Veblen et al., 1989, 1992; Speziale et al., 2010). The observed decrease in bamboo dominance was probably a major driver of understory dynamics in browsed humid forests (Raffaele et al., 2007), as reported in Asian temperate forests (Darabant et al., 2007). In contrast, drier forests comprised a larger proportion of low-growing herbs, which are less affected by grazing and perform better within open canopies (Veblen et al., 1996; Raffaele et al., 2011). This pattern of species dominance points to plant growth-defense tradeoffs (Coley et al., 1985) as a significant factor underlying the impact of domestic cattle along the moisture gradient (Milchunas et al., 1988; Proulx and Mazumder, 1998). A second, related mechanism was the increased addition of exclusive, rare species in cattle-disturbed communities of wetter forests. Browsed and unbrowsed stands in wetter sites also shared fewer species than their drier forest counterparts (Fig. A1). Our results suggest that ecological conditions differed more markedly between browsed and unbrowsed sites in the more productive, wetter habitats, a pattern already shown for grasslands (Milchunas and Lauenroth, 1993; Lezama et al., 2014). Yet, we cannot rule out the possibility that wetter forests comprised a larger species pool (Speziale et al., 2010), which would have increased the chances that new species colonized livestock disturbed stands (Leibold et al., 1997).

\subsection{Livestock impact on plant species diversity}

Based on existing models for grazing effects on local $(\alpha)$ diversity (Milchunas et al., 1988; Leibold et al., 1997), we expected a negative impact from livestock on understory species richness and evenness in drier forests, but a positive effect in wetter forests (Proulx and Mazumder, 1998; Hillebrand et al., 2007). We found, however, an overall decline in community evenness associated with long-term cattle presence (Fig. 4). In browsed understories, a larger amount of plant cover was concentrated in a few resistant species, mainly Adenocaulon chilense and Osmorhiza chilensis (forbs), Blechnum penna-marina (fern) and Berberis darwinii (spiny shrub) (see Table A3). Contrary to theoretical predictions, the effect of domestic cattle on species evenness did not vary with environmental moisture (Milchunas et al., 1988), and indeed was the opposite to the average effect reported for grass-dominated systems (Hillebrand et al., 2007). These findings support the notion that few species from the regional pool may be able to thrive under sustained livestock pressure in these Patagonian forests.

We did not detect an overall significant impact from livestock presence on local richness or effective diversity (Fig. $4 a$ and b). 
Previous work in temperate forests claimed that herbivore effects on understory species richness depended on canopy cover (Vázquez, 2002) or habitat productivity (Randall and Walters, 2011). Here, richness differences between paired sites were idiosyncratic, and unlike predictions from grazing models (Milchunas et al., 1988; Olff and Ritchie, 1998), cattle presence either increased or had no effect at all on species richness in both drier and wetter habitats (see Fig. A2). Although cattle had a disruptive effect on vegetation cover throughout the study gradient, colonization of browsed stands by ruderal herbs was highly variable among sites and was presumably counteracted by local species losses (Spear and Chown, 2009). It is also possible that a net species loss from browsed stands was prevented by microhabitat shelters created by fallen logs, coarse woody debris or spiny shrubs (Relva et al., 2008; Kuijper et al., 2015). Our sampling design was not adequate to reveal such detailed patterns, for which it would be necessary to perform a stratified, multi-scale sampling scheme, with nested plots of various sizes (Stohlgren, 2007).

Furthermore, it is also possible that sampling was not exhaustive enough to perceive between-site differences in plant richness generated by rare plant species. This might be due, in part, to the small size $\left(4 \mathrm{~m}^{2}\right)$ of the sample plots, and the use of regularly spaced, noncontiguous plots, which may underestimate local species richness in complex habitat settings (Stohlgren, 2007). Indeed, species accumulation curves suggested that in three out of five grazed stands our sampling did not capture the entire community richness, whereas for the remaining stands the cumulative richness leveled-off at small sample sizes (Fig. A2). Hence, our results may be conservative in regard to the impact of domestic cattle on understory plant richness in the study system.

Livestock altered the spatial heterogeneity of understory communities, although the direction of this effect depended on the scale of analysis (Senft et al., 1987). At the stand scale, the greater impact of domestic cattle on the species composition of moister forests was accompanied by increases in both $\alpha$ and $\beta$ diversity (Figs. 4a and 5a). Species colonizing cattle browsed stands were mostly opportunistic, low-growing forbs, including exotics with low cover values that were sparsely distributed within stands (see Table A3). These species were presumably displaced from livestock-free stands through competition with sub-canopy woody species and bamboo, a process that contributed to homogenize the community composition (cf. Darabant et al., 2007). Intriguingly, at the regional scale, the cumulative richness of browsed stands exceeded that of unbrowsed stands by $33 \%$, and this led to a generalized decrease in $\beta$ diversity along the moisture gradient (Fig. 5b). This pattern likely reflected a dynamic dispersal process whereby a common ensemble of plant species became established in livestock disturbed stands located in different habitat patches (Olff and Ritchie, 1988; Anderson et al., 2011).

\subsection{Leaf litter composition and diversity}

Introduced ungulates may often drive changes in plant communities that will influence soil ecosystem functioning (Wardle and Bardgett, 2004; Spear and Chown, 2009; Tanentzap and Coomes, 2011). Here we did not find an effect of livestock on the amount of leaf litter accumulated on the forest floor, although litter mass tended to decline along the moisture gradient, suggesting faster litter breakdown in wetter sites (see Fig. 6a). Similarly, Relva et al. (2014) reported no significant impact from removing introduced deer on $N$. dombeyi forest litter quantity and chemical quality, which could reflect the use of short-term ( $<10 \mathrm{yr}$-old) exclosures as surrogates for unbrowsed forest sites. More importantly, and contrary to short-term exclosure studies, we found that historical cattle disturbance altered litter composition and diversity by reducing the contribution of understory species to the litter layer
(Fig. 6b, Tables A5 and A6), irrespective of habitat context (cf. Mason et al., 2010). This result was consistent with the negative impact that livestock presence had on understory cover. Furthermore, litter species diversity decreased in browsed stands, as the bulk of leaf-litter production was dominated by $N$. dombeyi canopy trees. The homogenization of litter composition may have important consequences on soil communities and nutrient cycling processes (Lessard et al., 2012; Hatton et al., 2014). Whether mass litter production by dominant canopy tree species can eventually buffer herbivore-induced shifts in litter species diversity, as suggested for Nothofagus forests in New Zealand (Mason et al., 2010), remains an open question.

\subsection{Perspectives for conservation}

The temperate forests of Patagonia represent important reservoirs of biological diversity that warrant active protection (Mittermeier et al., 2003; Ezcurra and Brion, 2005). We have shown that the impact of introduced livestock on native forest understories stretches over a region-wide moisture gradient. While current stocking rates may be deceptively low, it must be realized that forest stands have been repeatedly used by livestock every year for many decades. Thus, the patterns reported here should reflect long-term, cumulative effects of domestic herbivores on understory vegetation. Nonetheless, given the observational nature of the paired-sites design, it must be recognized that other factors may have influenced the differences we found between livestock-free and disturbed forest stands.

In this light, our results suggest that a widespread shift towards a degraded vegetation state would have taken place under historical levels of cattle browsing. Further, the structural simplification of understory communities might accelerate the degradation process by facilitating the expansion of exotic species, which nowadays occur in low densities (Spear and Chown, 2009). We nevertheless posit that the recovery of certain vegetation attributes may still be possible given the large proportion of plant species shared between browsed and unbrowsed stands, and the rapid response of palatable species to ungulate removals (Veblen et al., 1992; Vázquez, 2002). There is, therefore, a pressing need for National Park authorities to introduce tighter controls on animal stocks, which might include culling of feral cattle as well as spatially-explicit management schemes (Wright et al., 2012), aimed at mitigating the ongoing loss of $N$. dombeyi understories. Our findings also indicate that moister forest habitats must be prioritized for conservation efforts, given their seemingly greater compositional susceptibility to livestock disturbance.

\section{Acknowledgements}

We are grateful to the National Parks Administration of Argentina for permitting us to work in Nahuel Huapi National Park and for the logistics provided throughout this project. We specially thank S. Seijas, L. Pussetto, J. Brunet, J.I. Jones, C. Apochian, S. Aguado, J. Santo, D. Núñez, for invaluable support and field assistance at various stages. M. Oleiro, N. Mazía, M. Mermoz, D. Irsúa, J. Karlanián, F. Maida, G. Millapán, L. Millapán, C. Piazza, P. Baldassini, and L. Ventura provided advice or helped with field and lab work. Species names were confirmed by Dr. Cecilia Ezcurra. Two reviewers provided helpful comments on early drafts. The study was funded by Agencia Nacional de Promoción Científica y Tecnológica - Argentina (BID-PICT Redes 2007-0284 and PICT 2011-0386) and a CONICET doctoral fellowship to the first author. 


\section{Appendix A. Supplementary material}

Supplementary data associated with this article can be found, in the online version, at http://dx.doi.org/10.1016/j.foreco.2016.01. 035. These data include Google maps of the most important areas described in this article.

\section{References}

Adler, P., Raff, D., Lauenroth, W., 2001. The effect of grazing on the spatial heterogeneity of vegetation. Oecologia 128, 465-479.

Anderson, M.J., Crist, T.O., Chase, J.M., Vellend, M., Inouye, B.D., Freestone, A.L., Sanders, N.J., Cornell, H.V., Comita, L.S., Davies, K.F., 2011. Navigating the multiple meanings of $\beta$ diversity: a roadmap for the practicing ecologist. Ecol. Lett. 14, 19-28.

Anderson, T.M., Ritchie, M.E., McNaughton, S.J., 2007. Rainfall and soils modify plant community response to grazing in Serengeti National Park. Ecology 88, 11911201.

Augustine, D.J., McNaughton, S.J., 1998. Ungulate effects on the functional species composition of plant communities: Herbivore selectivity and plant tolerance. J. Wildlife Manage. 62, 1165-1183.

Barros, V.R., Cordon, V.H., Moyano, C.L., Méndez, R.J., Forqera, J.C., Pizzio, O., 1983. Cartas de precipitación de la zona oeste de las provincias de Río Negro y Neuquén. Universidad Nacional del Comahue. Centro Nacional Patagónico, CONICET. Cinco Saltos, Río Negro.

Bryant, J.P., Chapin III, F.S., Klein, D.R., 1983. Carbon/nutrient balance of boreal plants in relation to vertebrate herbivory. Oikos, 357-368.

Chase, J.M., Leibold, M.A., Downing, A.L., Shurin, J.B., 2000. The effects of productivity, herbivory, and plant species turnover in grassland food webs. Ecology 81, 2485-2497.

Coley, P.D., Bryant, J.P., Chapin III, F.S., 1985. Resource availability and plant antiherbivore defense. Science 230, 895-899.

Coomes, D.A., Kunstler, G., Canham, C.D., Wright, E., 2009. A greater range of shadetolerance niches in nutrient-rich forests: an explanation for positive richnessproductivity relationships? J. Ecol. 97, 705-717.

Crist, T.O., Veech, J.A., 2006. Additive partitioning of rarefaction curves and speciesarea relationships: unifying $\alpha$-, $\beta$-and $\gamma$-diversity with sample size and habitat area. Ecol. Lett. 9-8, 923-932.

Darabant, A., Rai, P., Tenzin, K., Roder, W., Gratzer, G., 2007. Cattle grazing facilitates tree regeneration in a conifer forest with palatable bamboo understory. For. Ecol. Manage. 252, 73-83.

Díaz, S., Lavorel, S., McIntyre, S., Falczuk, V., Casanoves, F., Milchunas, D.G., Skarpe, C., Rusch, G., Sternberg, M., Noy-Meir, I., Landsberg, J., Zhang, W., Clark, H., Campbell, B.D., 2006. Plant trait responses to grazing - a global synthesis. Glob. Change Biol. 13, 313-341.

Didion, M., Kupferschmid, A.D., Wolf, A., Bugmann, H., 2011. Ungulate herbivory modifies the effects of climate change on mountain forests. Clim. Change 109, 647-669.

Ezcurra, C., Brion, C., 2005. Plantas del Nahuel Huapi. Catálogo de la flora vascular del Parque Nacional Nahuel Huapi, Argentina. 1 edition. Universidad Nacional del Comahue. Red Latinoamericana de Botánica., San Carlos de Bariloche, Argentina.

Ferrari, M., Pozzolo, O., Ferrari, H., 2008. Software CobCal. Page Basado en software Silk Icons. INTA EEA Concepción de Uruguay.

Frank, D.A., 2006. Large herbivores in heterogeneous grassland ecosystems. In: Danell, K., Bergström, R., Duncan, P., Pastor, J. (Eds.), Large Herbivore Ecology, Ecosystem Dynamics and Conservation. Cambridge University Press, Cambridge, UK, pp. 326-347.

Grime, J.P., 2001. Plant Strategies, Vegetation Processes, and Ecosystem Properties John Wiley \& Sons, Chichester.

Hanley, M.E., Lamont, B.B., Fairbanks, M.M., Rafferty, C.M., 2007. Plant structural traits and their role in anti-herbivore defence. Perspect. Plant Ecol., Evolut. Syst. 8, 157-178.

Hatton, P.J., Castanha, C., Torn, M.S., Bird, J.A., 2014. Litter type control on soil C and N stabilization dynamics in a temperate forest. Glob. Change Biol. 21, 13581367.

Haukioja, E., Koricheva, J., 2000. Tolerance to herbivory in woody vs. herbaceous plants. Evol. Ecol. 14, 551-562.

Hegland, S.J., Lilleeng, M.S., Moe, S.R., 2013. Old-growth forest floor richness increases with red deer herbivory intensity. For. Ecol. Manage. 310, 267-274.

Hill, M.O., 1973. Diversity and evenness: a unifying notation and its consequences. Ecology 54, 427-432.

Hillebrand, H., Gruner, D.S., Borer, E.T., Bracken, M.E., Cleland, E.E., Elser, J.J. Harpole, W.S., Ngai, J.T., Seabloom, E.W., Shurin, J.B., 2007. Consumer versus resource control of producer diversity depends on ecosystem type and producer community structure. Proc. Natl. Acad. Sci. USA 104, 10904-10909.

Jobbágy, E.G., Paruelo, J.M., León, R.J.C., 1995. Estimación del régimen de precipitación a partir de la distancia a la cordillera en el noroeste de la Patagonia. Ecología Austral 5, 47-53.

Knapp, A.K., Smith, M.D., 2001. Variation among biomes in temporal dynamics of aboveground primary production. Science 291, 481-484.
Krueger, L.M., Peterson, C.J., Royo, A., Carson, W.P., 2009. Evaluating relationships among tree growth rate, shade tolerance, and browse tolerance following disturbance in an eastern deciduous forest. Can. J. For. Res. 39, 2460-2469.

Kuijper, D.P.J., te Beest, M., Churski, M., Cromsigt, P.G.M., 2015. Bottom-up and topdown forces shaping wooded ecosystems: lessons from a cross-biome comparison. In: Hanley, T.C., Pierre, K.J.L. (Eds.), Trophic Ecology. Cambridge University Press, Cambridge, pp. 107-133.

Lauría Sorge, R.M., Romero, C.A., 1999. La ganadería doméstica de los pobladores con permiso de ocupación y pastaje (P.P.O.P.) en tierras fiscales del Parque Nacional Nahuel Huapi, San Carlos de Bariloche.

Leibold, M.A., Chase, J.M., Shurin, J.B., Downing, A.L., 1997. Species turnover and the regulation of trophic structure. Annu. Rev. Ecol. Syst. 28, 467-494.

Lessard, J.-P., Reynolds, W.N., Bunn, W.A., Genung, M.A., Cregger, M.A., FelkerQuinn, E., Barrios-Garcia, M.N., Stevenson, M.L., Lawton, R.M., Brown, C.B., 2012. Equivalence in the strength of deer herbivory on above and below ground communities. Basic Appl. Ecol. 13, 59-66.

Lezama, F., Baeza, S., Altesor, A., Cesa, A., Chaneton, E.J., Paruelo, J.M., 2014. Variation of grazing-induced vegetation changes across a large-scale productivity gradient. J. Veg. Sci. 25, 8-21.

Magurran, A.E., 1988. Ecological Diversity and Its Measurement. Princeton University Press, Princeton, New Jersey.

Martin, J.-L., Stockton, S.A., Allombert, S., Gaston, A.J., 2010. Top-down and bottomup consequences of unchecked ungulate browsing on plant and animal diversity in temperate forests: lessons from a deer introduction. Biol. Invasions 12, 353-371.

Mason, N.W.H., Peltzer, D.A., Richardson, S.J., Bellingham, P.J., Allen, R.B., 2010 Stand development moderates effects of ungulate exclusion on foliar traits in the forests of New Zealand. J. Ecol. 98, 1422-1433.

Milchunas, D.G., Lauenroth, W.K., 1993. Quantitative effects of grazing on vegetation and soils over a global range of environments. Ecol. Monogr. 63, 327-366.

Milchunas, D.G., Sala, O.E., Lauenroth, W.K., 1988. A generalized model of the effects of grazing by large herbivores on grassland community structure. Am. Natur. 132, 87-106.

Mittermeier, R., Mittermeier, C., Brooks, T., Pilgrim, J., Konstant, W., Da Fonseca, G.A., Kormos, C., 2003. Wilderness and biodiversity conservation. Proc. Natl. Acad. Sci. USA 100, 10309-10313.

Nuttle, T., Yerger, E.H., Stoleson, S.H., Ristau, T.E., 2011. Legacy of top-down herbivore pressure ricochets back up multiple trophic levels in forest canopies over 30 years. Ecosphere 2, art4.

Oksanen, J., Blanchet, G.F., Kindt, R., Legendre, P., Minchin, P.R., O'Hara, R.B., Simpson, G.L., Solymos, P., Stevens, M.H.H., Wagner, H., 2011. Vegan: Community Ecology Package. R package version 2.0-2. <http://CRAN.R-project. org/package=vegan>.

Olff, H., Ritchie, M.E., 1998. Effects of herbivores on grassland plant diversity. Trends Ecol. Evol. 13, 261-265.

ORNL DAAC, 2008. MODIS Collection 5 Land Products Global Subsetting and Visualization Tool. ORNL DAAC, Oak Ridge, Tennessee, USA. <http://dx.doi.org/ 10.3334/ORNLDAAC/1241>.

Pastor, J., Cohen, Y., 1997. Herbivores, the functional diversity of plants species, and the cycling of nutrients in ecosystems. Theor. Popul. Biol. 51, 165-179.

Persson, I.L., Pastor, J., Danell, K., Bergström, R., 2005. Impact of moose population density on the production and composition of litter in boreal forests. Oikos 108, 297-306.

Pettorelli, N., Vik, J.O., Mysterud, A., Gaillard, J.-M., Tucker, C.J., Stenseth, N.C., 2005. Using the satellite-derived NDVI to assess ecological responses to environmental change. Trends Ecol. Evol. 20, 503-510.

Pinheiro, J.C., Bates, D.M., 2000. Mixed-Effects Models in S and S-PLUS. Springer, New York, USA.

Pinheiro, J., Bates, D., DebRoy, S., Sarkar, D., R Development Core Team, 2011. nlme: Linear and Nonlinear Mixed Effects Models. R package version 3.1-100.

Proulx, M., Mazumder, A., 1998. Reversal of grazing impact on plant species richness in nutrient-poor vs. nutrient-rich ecosystems. Ecology 79, 25812592.

R Development Core Team, 2011. R: A Language and Environment for Statistical Computing. R Foundation for Statistical Computing, Vienna, Austria.

Raffaele, E., Kitzberger, T., Veblen, T., 2007. Interactive effects of introduced herbivores and post-flowering die-off of bamboos in Patagonian Nothofagus forests. J. Veg. Sci. 18, 371-378.

Raffaele, E., Veblen, T.T., Blackhall, M., Tercero-Bucardo, N., 2011. Synergistic influences of introduced herbivores and fire on vegetation change in northern Patagonia, Argentina. J. Veg. Sci. 22, 59-71.

Randall, J.A., Walters, M.B., 2011. Deer density effects on vegetation in aspen forest understories over site productivity and stand age gradients. For. Ecol. Manage. 261, 408-415.

Relva, M.A., Westerholm, C.L., Kitzberger, T., 2008. Effects of introduced ungulates on forest understory communities in northern Patagonia are modified by timing and severity of stand mortality. Plant Ecol. 201, 11-22.

Relva, M.A., Castán, E., Mazzarino, M.J., 2014. Litter and soil properties are not altered by invasive deer browsing in forests of NW Patagonia. Acta Oecol. 54, 45-50.

Relva, M.A., Nuñez, M.A., Simberloff, D., 2010. Introduced deer reduce native plant cover and facilitate invasion of non-native tree species: evidence for invasional meltdown. Biol. Invasions 12, 303-311. 
Royo, A.A., Stout, S.L., deCalesta, D.S., Pierson, T.G., 2010. Restoring forest herb communities through landscape-level deer herd reductions: is recovery limited by legacy effects? Biol. Conserv. 143, 2425-2434.

Senft, R., Coughenour, M., Bailey, D., Rittenhouse, L., Sala, O., Swift, D., 1987. Large herbivore foraging and ecological hierarchies. Bioscience, 789-799.

Spear, D., Chown, S.L., 2009. Non-indigenous ungulates as a threat to biodiversity. J. Zool. 279, 1-17.

Speziale, K.L., Ruggiero, A., Ezcurra, C., 2010. Plant species richness-environment relationships across the Subantarctic-Patagonian transition zone. J. Biogeogr. 37, 449-464.

Stohlgren, T.J., 2007. Measuring Plant Diversity: Lessons from the Field. OUP USA. Oxford University Press, USA.

Suzuki, M., Miyashita, T., Kabaya, H., Ochiai, K., Asada, M., Kikvidze, Z., 2013. Deer herbivory as an important driver of divergence of ground vegetation communities in temperate forests. Oikos 122, 104-110.

Tanentzap, A.J., Coomes, D.A., 2011. Carbon storage in terrestrial ecosystems: do browsing and grazing herbivores matter? Biol. Rev. 87, 72-94.

Vázquez, D.P., 2002. Multiple effects of introduced mammalian herbivores in a temperate forest. Biol. Invasions 4, 175-191.
Veblen, T.T., Donoso, C., Kitzberger, T., Rebertus, A.J., 1996. Ecology of Southern Chilean and Argentinean Nothofagus Forests. In: Veblen, T.T., Hill, R.S., Read, J. (Eds.), The Ecology and Biogeography of Nothofagus Forests. Yale University Press, New Haven.

Veblen, T.T. Mermoz, M., Martin, C. Ramilo, E. 1989. Effects of exotic deer on forest regeneration and composition in northern Patagonia. J. Appl. Ecol., 711-724

Veblen, T.T., Mermoz, M., Martin, C., Kitzberger, T., 1992. Ecological impacts of introduced animals in Nahuel Huapi National Park, Argentina. Conserv. Biol. 6, $71-83$.

Vila, A.R., Borrelli, L., 2011. Cattle in the Patagonian forests: feeding ecology in Los Alerces National Reserve. For. Ecol. Manage. 261, 1306-1314.

Wardle, D.A., Bardgett, R.D., 2004. Human-induced changes in large herbivorous mammal density: the consequences for decomposers. Front. Ecol. Environ. 2 $145-153$.

Wright, D.M., Tanentzap, A.J., Flores, O., Husheer, S.W., Duncan, R.P., Wiser, S.K., Coomes, D.A., 2012. Impacts of culling and exclusion of browsers on vegetation recovery across New Zealand forests. Biol. Conserv. 153, 64-71. 